\title{
An update on the detection and treatment of Rickettsia felis
}

\author{
This article was published in the following Dove Press journal: \\ Research and Reports in Tropical Medicine \\ 21 June 2012 \\ Number of times this article has been viewed
}

\section{Laya Hun \\ Adriana Troyo}

Centro de Investigación en Enfermedades Tropicales, Facultad de Microbiología, Universidad de Costa Rica, San José, Costa Rica
Correspondence: Laya Hun Sección de Virología, Centro de Investigación en Enfermedades Tropicales, Facultad de Microbiología, Universidad de Costa Rica, Sede Rodrigo Facio Brenes, Montes de Oca, San José 2060, Costa Rica Tel +50625 II 4363

Fax +506 22254384

Email ruchlia.hun@ucr.ac.cr
Abstract: Rickettsia felis was described as a human pathogen almost two decades ago, and human infection is currently reported in 18 countries in all continents. The distribution of this species is worldwide, determined by the presence of the main arthropod vector, Ctenocephalides felis (Bouché). The list of symptoms, which includes fever, headache, myalgia, and rash, keeps increasing as new cases with unexpected symptoms are described. Moreover, the clinical presentation of $R$. felis infection can be easily confused with many tropical and nontropical diseases, as well as other rickettsial infections. Although specific laboratory diagnosis and treatment for this flea-borne rickettsiosis are detailed in the scientific literature, it is possible that most human cases are not being diagnosed properly. Furthermore, since the cat flea infests different common domestic animals, contact with humans may be more frequent than reported. In this review, we provide an update on methods for specific detection of human infection by $R$. felis described in the literature, as well as the treatment prescribed to the patients. Considering advances in molecular detection tools, as well as options for as-yet-unreported isolation of $R$. felis from patients in cell culture, increased diagnosis and characterization of this emerging pathogen is warranted.

Keywords: Rickettsia felis, human cases, laboratory diagnosis, treatment

\section{Introduction}

Rickettsia felis is considered an emerging human pathogen and the etiologic agent of flea-borne rickettsiosis, also known as flea-borne spotted fever and cat flea typhus. Rickettsioses are arthropod-borne diseases caused by obligate rod-shaped, intracellular Gram-negative $\alpha$-proteobacteria of the genus Rickettsia, which can infect humans and different animals. ${ }^{1}$ The genus Rickettsia has been divided into three major groups based on their antigenic and genetic characteristics: (1) the spotted fever group (SFG), which includes several nonpathogenic as well as pathogenic species such as the etiological agents of Rocky Mountain spotted fever/Brazilian spotted fever (Rickettsia rickettsii), Mediterranean spotted fever (R. conorii), flea-borne spotted fever ( $R$. felis), rickettsial pox (R. akari), R. massiliae, and R. slovaca; (2) the typhus group (TG), which includes the etiological agents of epidemic and endemic typhus ( $R$. prowazekii and $R$. typhi); and (3) the ancestral group, containing $R$. belli and $R$. canadensis. ${ }^{2-4}$ Although a fourth group has been proposed more recently, which separates $R$. akari, $R$. australis, and $R$. felis from the SFG and places them in a separate group called the transitional group, ${ }^{5,6}$ the validity of a separate group for these species has been debated. ${ }^{7,8}$

$R$. felis was first observed by electron microscopy from midgut epithelial cells and other tissues of adult cat fleas (Ctenocephalides felis felis), and it was named "ELB" 
after El-Labs (Soquel, CA). ${ }^{9}$ A close affinity of ELB to $R$. typhi was demonstrated initially by immunofluorescence assays. ${ }^{9,10}$ Additional characterization of the ELB agent followed, and evidence from polymerase chain reaction (PCR) amplification, restriction fragment length polymorphism (RFLP) analyses, and sequencing of the $17 \mathrm{kDa}$ protein and citrate synthase gene ( $g l t A)$ fragments indicated that ELB was distinct from $R$. typhi.$^{10-12}$ Other studies confirmed this same fact, and description of the organism as $R$. felis was performed by Higgins et al in $1996 .{ }^{13}$ Initial isolation and cultivation had been reported by Radulovic et al, ${ }^{11}$ but maintenance in culture was not possible at the time, and contamination with R. typhi was suspected. ${ }^{14}$ In 2001, Bouyer et al amplified the recombinant outer membrane protein A gene (omp $A$ ) by PCR, a gene present only in SFG rickettsiae. ${ }^{14}$ Although previous evidence from analysis of other gene sequences suggested placement of $R$. felis in the $\mathrm{SFG},{ }^{2,10}$ this evidence of ompA finally confirmed that the new Rickettsia was in fact a member of the SFG. Rickettsia felis was further characterized and redescribed, and descriptions were emended in 2002. ${ }^{14,15}$

A study by Merhej et al showed that most genes of $R$. felis genome place it in the SFG clade. ${ }^{8}$ However, phylogenetic analyses of $R$. felis genes revealed that some of them come from a variety of origins, as has been shown for other bacteria like Escherichia coli, which demonstrates that not all genes show vertical inheritance during evolutionary history and that horizontal gene transfer probably occurs. Rickettsia felis can acquire new genes horizontally, since it has been shown that this species is present in many different hosts, ${ }^{16-28}$ and concomitant infections by more than one intracellular bacterium may lead to recombination events. ${ }^{8}$ It has also been demonstrated that $R$. felis can have one, two, or no plasmids, which were probably acquired through horizontal exchange by conjugation. ${ }^{5,29-31}$ Although studies have recognized all genes in the different $R$. felis studied, their function is not all clear. It would be important in future to determine if those newly acquired genes could change characteristics like tropism or antigenicity.

\section{$R$. felis infection in invertebrate and vertebrate animals}

The ecology of $R$. felis has been reviewed previously, $22,32-34$ and although it is not the focus of this review, some general considerations are presented concerning infection and detection in vertebrate and invertebrate hosts.

The cat flea, $C$. felis felis, is considered the primary vector and reservoir of $R$. felis. Detection of $R$. felis DNA in these fleas has been successful everywhere it has been investigated.
Given that the cat flea is cosmopolitan in distribution, the presence of $R$. felis follows this same pattern, and has been already reported in every continent except Antarctica. ${ }^{10,17,35-41}$ However, R. felis is not restricted to C. felis, and molecular evidence of infection, although less frequent, has been reported in other species of arthropods, such as fleas, ticks, and mites, including the familiar species Ctenocephalides canis, Xenopsylla cheopis, Pulex irritans, Tunga penetrans, Echidnophaga gallinacea, Rhipicephalus sanguineus, Amblyomma cajennense, chiggers (Trombiculidae), and even in nonbiting insects. ${ }^{19,20,22-28,34,35}$

In most of these cases, the presence of $R$. felis in arthropods has been confirmed by detection and sequencing or RFLP analyses of rickettsia-specific gene fragments, the most common being gltA, htrA (17 kDa protein), omp $A$, and ompB. ${ }^{22}$ Quantitative real-time PCR (qPCR) assays to detect $R$. felis DNA in fleas have also been developed and are useful in determining infection load and kinetics. ${ }^{42,43}$ Conversely, successful isolation and culture of $R$. felis directly from cat fleas has been reported only from laboratories in France, the US, Brazil, and Costa Rica using cell lines of vertebrate (XTC-2 and Vero) and arthropod (ISE6 and C6/36) origin. ${ }^{36,44-46}$ No isolation of $R$. felis from vertebrates has been reported. The conditions of cultivation and growth of $R$. felis in different cell lines are described later in this review.

Rickettsia felis is maintained in flea populations mainly by transovarial transmission. ${ }^{10,47}$ Evidence also suggests horizontal transmission from other infected fleas or infection through a rickettsemic blood meal is likely. ${ }^{48,49}$ Although there is no evidence of fitness loss or increased mortality in infected $C$. felis, results of some studies suggest that $R$. felis may actually increase fitness to facilitate transmission to the next generation of fleas or a vertebrate host. ${ }^{43}$

Infection of vertebrates probably occurs during blood feeding of infected fleas, although transmission through infective flea feces is possible. ${ }^{47,50}$ Various domestic and peridomestic animals may exhibit evidence of $R$. felis natural infection. Antibodies against $R$. felis can be present in animals, including dogs, cats, and opossums, and the presence of specific DNA fragments has also been detected in animals. ${ }^{51-62}$ Since acquisition of $R$. felis from blood meal and transmission from fleas to animals has been demonstrated in laboratory experiments, ${ }^{47,49}$ cats, dogs, and opossums have been considered possible reservoirs. ${ }^{13,53,57,62}$

Symptomatic disease caused by $R$. felis infection in domestic or wild animals may vary, but a direct causal association has not been proven. One study showed no statistical association between presence of $R$. felis antibodies and 
illness in cats,${ }^{56}$ and another report mentions a PCR-positive dog with fatigue and digestive symptoms. ${ }^{54}$ In addition, an experimental infection of opossums with $R$. felis resulted in antibody response, although bacteremia was undetectable. ${ }^{61}$ Given that isolation of $R$. felis directly from sick animals has not been performed so far and that prevalence of infection and/or rickettsemia may not be high, ${ }^{56,63-65}$ there is no conclusive evidence at this time to confirm the role of these animals as reservoirs or victims of disease.

\section{Human cases of flea-borne spotted fever}

Human infection with $R$. felis has already been reported in the US, ${ }^{66}$ Mexico,${ }^{67-69}$ Brazil, ${ }^{36}$ France, ${ }^{36,70}$ Germany, ${ }^{52}$ Spain, ${ }^{54,71}$ Sweden, ${ }^{72}$ Israel, ${ }^{73}$ South Korea, ${ }^{74}$ Taiwan, ${ }^{75}$ Thailand, ${ }^{76}$ Laos, ${ }^{77}$ Tunisia,${ }^{78,79}$ Egypt,${ }^{80}$ Australia,${ }^{81}$ Senegal, ${ }^{82}$ Kenya,${ }^{83,84}$ and New Zealand. ${ }^{85}$

Clinical findings for $R$. felis infection may be confused with infection due to other rickettsial agents like $R$. typhi and some members of the SFG, as well as other infectious diseases like dengue, malaria, brucellosis, leptospirosis, or even other clinical conditions like Kawasaki disease. ${ }^{69,77,81,83}$ One example of misdiagnosis is a case reported as murine typhus diagnosed by serology in 2008, which in 2010 was confirmed by PCR as an infection by $R$. felis and not $R$. typhi, using the patient's same frozen serum. ${ }^{73}$

Fever (greater than $38^{\circ} \mathrm{C}$ ), headache, myalgia, and maculopapular rash are the most common symptoms. ${ }^{66}$ The presence of a cutaneous eschar at the bite site is possible, although it may be infrequent. ${ }^{52,70}$ Respiratory and digestive symptoms, including cough, pulmonary edema, pneumonia, nausea, vomiting, and diarrhea, have been reported. . $^{35,67,70,86}$ Neurological signs have also been documented, such as the reports of infection in patients presenting subacute meningitis and acute polyneuropathy-like symptoms from Sweden and Taiwan, respectively. ${ }^{72,75}$ Although $R$. felis infection in most cases has been observed as a mild to moderate illness, respiratory, neurologic, and visceral affections can occur, leading to complications such as those reported in severe cases from Mexico. ${ }^{69}$ Although no deaths attributed to $R$. felis infection are reported in the literature, the first two cases reported from Brazil presented stupor, and one of them coma. ${ }^{36}$

During $R$. felis infection, laboratory results for tests like hematocrit and hemoglobin are usually in the normal range, but some patients have severe thrombocytopenia and elevated bilirubin $(2.7-3.1 \mathrm{mg} / \mathrm{dL})$, which presents as jaundice. ${ }^{69}$ The most common abnormalities are associated with increased aminotransferase levels: aspartate aminotransferase (85-108 U/L) and alanine aminotransferase (135-160 U/L). ${ }^{69,70,81}$

Knowledge of epidemiological context, clinical history, signs, symptoms, and general laboratory tests are important for diagnosis of rickettsial diseases. Since infection with $R$. felis can cause illness anywhere from mild to moderate to severe, it may be confused with signs and symptoms of other infectious and noninfectious diseases. Therefore, diagnosis of flea-borne spotted fever requires specific laboratory tests to detect $R$. felis infection.

\section{Laboratory detection of $\boldsymbol{R}$. felis infection in humans}

Methods for detection of $R$. felis infection in humans are derived from the general methods used in diagnosis for rickettsial diseases. Although the general principles and applications of these methods have been reviewed previously, $3,87,88$ the following section describes their applications in detection of specific $R$. felis infection.

\section{Detection of antibodies}

Specific methods for the diagnosis of rickettsial diseases of the SFG in humans started in the late 1960s utilizing serologic tests, the immunofluorescent antibody assay being the reference method for detection of specific antibodies to SFG rickettsiae. ${ }^{89,90}$ The most important limitation of serologic tests is the cross-reaction that occurs between species of rickettsiae within the same group and sometimes even between groups. Although this cross-reaction is common between species, ${ }^{91-93}$ immunofluorescence is considered the reference method for diagnosis of rickettsial infection. ${ }^{3,87,88}$ It is also the first step towards the diagnosis and screening of rickettsial diseases for mainly nonendemic geographic areas. ${ }^{94}$ Twofold serial dilutions of the sera should be performed to determine an end titer using antigens from one or more species of rickettsiae. Absorption of sera with complementary rickettsiae can be useful when cross-reactivity occurs, and Western blot may also aid in species identification. ${ }^{3,95}$

Detection of antibodies to SFG or TG rickettsiae in human infections with $R$. felis has been performed by immunofluorescence methods in some of the cases reported, although species confirmation has been determined by other means (Table 1). A general guideline used for identification of the rickettsial agent responsible is mentioned in several of the reports. ${ }^{3}$ According to this, if cross-reactivity occurs, a higher titer of antibodies to $R$. felis in comparison to other species (usually by two or more serial dilutions) would suggest specific infection by $R$. felis or a very similar species. ${ }^{36,76}$ 
Table I Summary of Rickettsia felis-specific diagnostic/confirmatory methods and treatment reported in human infection

\begin{tabular}{|c|c|c|c|c|c|}
\hline Country & $\begin{array}{l}\text { Year of } \\
\text { publication }\end{array}$ & $\begin{array}{l}\mathbf{N} \text { cases } \\
\text { confirmed }\end{array}$ & $\begin{array}{l}\text { R. felis-specific detection } \\
\text { and identification methods* }\end{array}$ & $\begin{array}{l}\text { Specific } R \text {. felis treatment } \\
\text { and outcome }\end{array}$ & Reference \\
\hline USA & 1994 & 1 & $\begin{array}{l}\text { PCR I7-kDa protein gene fragment } \\
\text { RFLP Southern hybridization }\end{array}$ & Doxycycline & 66 \\
\hline Brazil & 2001 & 2 & $\begin{array}{l}\text { MIF antibody titers to } R \text {. felis higher } \\
\text { by two or more dilutions } \\
\text { Nested PCR gltA gene fragment, } \\
\text { sequencing (I patient) }\end{array}$ & $\mathrm{NI}$ & 36 \\
\hline \multirow[t]{3}{*}{ Mexico } & 2000 & 3 & $\begin{array}{l}\text { PCR 17-kDa protein gene } \\
\text { fragment; sequencing }\end{array}$ & $\begin{array}{l}\text { Doxycycline } 2 \text { weeks (one patient), } \\
\text { recovered }\end{array}$ & 67 \\
\hline & 2006 & I & $\begin{array}{l}\text { PCR I7-kDa protein gene } \\
\text { fragment, sequencing }\end{array}$ & $\begin{array}{l}\text { Doxycycline, discharged after I week } \\
\text { Chloramphenicol }\end{array}$ & 68 \\
\hline & 2009 & 2 & $\begin{array}{l}\text { PCR gltA, ompA, ompB, gene } \\
\text { fragments, sequencing and RFLP }\end{array}$ & $\begin{array}{l}\text { (IV } 75 \mathrm{mg} / \mathrm{kg} \text { per day for } 10 \text { days), } \\
\text { both recovered within } 5 \text { days }\end{array}$ & 69 \\
\hline \multirow[t]{2}{*}{ France } & 2001 & 2 & $\begin{array}{l}\text { MIF antibody titers to } R \text {. felis } \\
\text { higher by two or more dilutions }\end{array}$ & $\mathrm{NI}$ & 36 \\
\hline & 2009 & 1 & $\begin{array}{l}\text { MIF, R. felis confirmed by Western } \\
\text { blot with cross-adsorption }\end{array}$ & Doxycycline, rapid improvement & 70 \\
\hline Germany & 2002 & 1 & $\begin{array}{l}\text { Seroconversion, MIF antibody titers to } \\
R \text {. felis higher by two or more dilutions, } \\
\text { species confirmed by Western blot } \\
\text { Nested PCR for PSI } 20 \text { protein } \\
\text { gene fragment }\end{array}$ & $\begin{array}{l}\text { Doxycycline ( } 200 \mathrm{mg} / \text { day for } 7 \text { days), } \\
\text { recovered within } 3 \text { days }\end{array}$ & 52 \\
\hline Thailand & 2003 & 1 & $\begin{array}{l}\text { MIF antibody titers to } R \text {. felis higher by } \\
\text { two or more dilutions, species } \\
\text { confirmed by Western blot }\end{array}$ & Doxycycline (200 mg/day for 7 days) & 76 \\
\hline $\begin{array}{l}\text { South } \\
\text { Korea }\end{array}$ & 2005 & 3 & $\begin{array}{l}\text { Nested PCRs ompB and gltA gene } \\
\text { fragments, RFLP and sequencing }\end{array}$ & $\mathrm{NI}$ & 74 \\
\hline \multirow[t]{2}{*}{ Spain } & 2005 & 5 & $\begin{array}{l}\text { MIF antibody titers to } R \text {. felis higher by } \\
\text { two or more dilutions, species confirmed } \\
\text { by Western blot with cross-adsorption }\end{array}$ & $\mathrm{NI}$ & 54 \\
\hline & 2006 & 2 & $\begin{array}{l}\text { Nested PCRs gltA and ompB gene fragment, } \\
\text { seminested PCR ompA, sequencing }\end{array}$ & $\begin{array}{l}\text { Doxycycline ( } 200 \mathrm{mg} / \text { day for } 10 \text { days), } \\
\text { recovered within } 2 \text { days }\end{array}$ & 71 \\
\hline \multirow[t]{2}{*}{ Tunisia } & 2006 & 8 & MIF, Western blot with cross-adsorption & $\mathrm{NI}$ & 78 \\
\hline & 2009 & 1 & MIF, Western blot with cross-adsorption & Tetracycline and doxycycline & 79 \\
\hline Laos & 2006 & I & MIF, Western blot with cross-adsorption & $\mathrm{NI}$ & 77 \\
\hline Egypt & 2007 & 1 & $\begin{array}{l}\text { Quantitative real-time PCR specific } \\
\text { for } R \text {. felis ompB gene fragment }\end{array}$ & $\mathrm{NI}$ & 80 \\
\hline Israel & 2010 & 1 & $\begin{array}{l}\text { Quantitative real-time PCR specific } \\
\text { for } R \text {. felis ompB gene fragment }\end{array}$ & Doxycycline & 73 \\
\hline \multirow[t]{2}{*}{ Kenya } & 2010 & 6 & $\begin{array}{l}\text { Quantitative real-time and nested PCR } \\
\text { I7 kDa protein gene fragments, sequencing } \\
\text { Quantitative real-time PCR specific for } \\
\text { R. felis ompB gene fragment } \\
\text { Nested PCR ompB gene fragment, sequencing }\end{array}$ & $\mathrm{NI}$ & 83 \\
\hline & 2012 & 21 & $\begin{array}{l}\text { PCR R. felis plasmid } \\
\text { PCR I7-kDa protein gene, ompB, } \\
\text { R. felis plasmid gene fragments, sequencing } \\
\text { Quantitative real-time PCR specific } \\
\text { for R. felis ompB gene fragment }\end{array}$ & $\mathrm{NI}$ & 84 \\
\hline Australia & 2011 & 5 (probable) & $\begin{array}{l}\text { MIF, high titers or seroconversion } \\
\text { to TG rickettsiae } \\
\text { PCR gltA gene fragment from } \\
\text { cat fleas, sequencing }\end{array}$ & $\begin{array}{l}\text { Doxycycline (one patient), } \\
\text { improved }\end{array}$ & 81 \\
\hline Senegal & 2010 & 8 & $\begin{array}{l}\text { Quantitative real-time and nested } \\
\text { PCR gltA gene fragments, sequencing } \\
\text { Quantitative real-time PCR biotin synthase } \\
\text { R. felis-specific gene fragment }\end{array}$ & $\mathrm{NI}$ & 82 \\
\hline
\end{tabular}


Table I (Continued)

\begin{tabular}{|c|c|c|c|c|c|}
\hline Country & $\begin{array}{l}\text { Year of } \\
\text { publication }\end{array}$ & $\begin{array}{l}\mathbf{N} \text { cases } \\
\text { confirmed }\end{array}$ & $\begin{array}{l}\text { R. felis-specific detection } \\
\text { and identification methods* }\end{array}$ & $\begin{array}{l}\text { Specific } R \text {. felis treatment } \\
\text { and outcome }\end{array}$ & Reference \\
\hline Taiwan & 2008 & I & $\begin{array}{l}\text { Quantitative real-time PCR I7-kDa protein, } \\
\text { groEL, ompB gene fragments, sequencing }\end{array}$ & $\begin{array}{l}\text { Doxycycline (oral } 100 \text { mg } \\
\text { every } 12 \text { hours for } 5 \text { days) }\end{array}$ & 75 \\
\hline Sweden & 2010 & 2 & $\begin{array}{l}\text { Quantitative real-time PCR gltA; nested } \\
\text { PCR I7-kDa protein and ompB gene } \\
\text { fragments, sequencing }\end{array}$ & Nonspecific antibiotics & 72 \\
\hline $\begin{array}{l}\text { New } \\
\text { Zealand }\end{array}$ & 2012 & 2 & $\begin{array}{l}\text { MIF, R. felis confirmed by Western } \\
\text { blot with cross-adsorption }\end{array}$ & $\mathrm{NI}$ & 85 \\
\hline
\end{tabular}

Note: *PCRs not specific for $R$. felis unless otherwise stated.

Abbreviations: PCR, polymerase chain reaction; RFLP, restriction fragment length polymorphism; MIF, microimmunofluorescence; NI, not indicated or not applicable.

In addition, confirmation of $R$. felis antibodies has been performed by Western blot and/or cross-adsorption analyses. ${ }^{70,71,76-78}$ However, these methods may not determine the species of Rickettsia responsible in every case. ${ }^{52,71,78,85}$

The presence of immunoglobulin $\mathrm{G}$ ( $\mathrm{IgG}$ ) antibodies in humans, which probably represent past infection with $R$. felis, has been demonstrated and may be relatively frequent. ${ }^{85,93,96}$ Considering that the presence of $\operatorname{IgG}$ antibodies to $R$. felis does not necessarily mean current infection, demonstration of specific seroconversion to $R$. felis is required and has been used to confirm the presence of $R$. felis using immunological methods ${ }^{52}$ However, this is not without limitations, since seroconversion for IgG may appear a month or more after rickettsial infection.

\section{Molecular methods}

Rickettsia felis infection has been frequently diagnosed by PCR amplification of targeted genes. Samples are usually whole blood or serum, although highly sensitive nested and/or real-time PCR assays may be required to detect very low concentrations of rickettsial DNA present in serum. In a recent report from Sweden, R. felis DNA was detected in cerebrospinal fluid from two patients. ${ }^{72}$ The genes most commonly amplified are gltA, ompB, and htrA. The отрA gene has also been used, although detection can be variable. ${ }^{54,69}$ Several of the published reports indicate that $R$. felis was detected by amplifying more than two genes, and amplicons were confirmed as $R$. felis by sequencing in most cases (Table 1).

Sequencing of PCR products is usually necessary in order to get a definitive identification, considering that these genes are present in all SFG rickettsiae and only specific variations in each sequence allow differentiation. It has been difficult to properly standardize qPCR to separate between different SFG rickettsiae; nevertheless, real-time PCR methods have been developed specifically for $R$. felis gene fragments, including $о т p B$ and the biotin synthase gene. ${ }^{42,82,97}$ This approach has been used to detect R. felis-specific infection in humans, which eliminates the need for sequencing (Table 1). ${ }^{73,80,82,83}$

\section{Isolation in cell culture}

Isolation of $R$. felis from human cases in cell culture has not been reported; it has only been documented from invertebrates. The best samples for isolation attempts, as is true for other SFG rickettsiae, would be blood and skin biopsies, mainly from the eschar zone if present. ${ }^{3,87}$ Although different cells like Vero (primate), XTC-2 (amphibian), C6/36 (Aedes albopictus), ISE6 (tick), Aa23 (A. albopictus), Sua5B (Anopheles gambiae), L929 (mouse), and HUVEC (human) have been shown to support $R$. felis growth, ${ }^{11,36,44-46,98-101}$ the cell lines have either not been successful for isolation of $R$. felis from human samples, or this has not been attempted.

Successful isolates from fleas reported, for instance, that R. felis was detected in XTC-2 cells after 14 days in initial isolation and after 6 days in subsequent passages, while growth was half the rate in Vero cells. ${ }^{36}$ Initial detection of $R$. felis growth in cell culture is usually determined by Giménez stain. Growth is optimal at $28^{\circ} \mathrm{C}$ in XTC-2 cells, and growth has been demonstrated at $28^{\circ} \mathrm{C}$ and $32^{\circ} \mathrm{C}$ in Vero, room temperature in $\mathrm{Aa} 23$ and Sua5B, $25^{\circ} \mathrm{C}$ and $28^{\circ} \mathrm{C}$ in $\mathrm{C} 6 / 36$, and $32^{\circ} \mathrm{C}$ in ISE6 cell lines. ${ }^{36,44} 46,98$ Plaque production is reported at 9 and 18 days in XTC-2 and Vero cells, respectively, ${ }^{15}$ while almost $100 \%$ infection is reported in Aa23 and Sua5B cells within 7 days of passaging. ${ }^{98}$

Isolation and propagation reports show that $R$. felis grows better at lower temperatures, in agreement with the usual conditions of their invertebrate host. Since optimal temperature for growth of mammalian cells is usually higher, replication of $R$. felis may be reduced or does not occur. Nevertheless, Saisongkorh et al report the establishment of $R$. felis for up to ten passages in mammalian cells (Vero and L 929) at $28^{\circ} \mathrm{C}$, enhanced by using $4 \%$ of tryptose phosphate broth 
as a supplement in minimum essential medium (MEM) cell culture medium with $2 \%$ fetal bovine serum. ${ }^{101}$

Growth of $R$. felis in these various vertebrate and invertebrate cell lines is possible, although isolation from human or other vertebrates has not been reported in the literature. In other species such as $R$. rickettsii, different strains have shown varying virulence depending on the vector or host species of isolation. ${ }^{102,103}$ Therefore it is of utmost importance to attempt isolation of the bacterium, especially from human cases with apparent disease. If culture is successful, isolates of $R$. felis from symptomatic patients would allow further characterization of virulence factors, pathogenic potential, and course of infection of these pathogenic strains.

\section{Clinical treatment}

Whenever signs and symptoms suggest rickettsial disease, treatment should be started immediately, even before laboratory diagnosis is complete. Doxycycline (200 mg per day) is the antibiotic of choice for spotted fever rickettsioses. ${ }^{104-106}$ These general guidelines have also been applied in flea-borne rickettsiosis (Table 1). For pregnant patients or patients who are allergic to this drug, disease may be treated with chloramphenicol. In severe cases, intravenous antibiotic is recommended for at least 24-48 hours after defervescence of fever. As with other rickettsioses, doxycycline is the antibiotic of choice for complicated cases of flea-borne typhus, although chloramphenicol has been used successfully to treat severe cases. ${ }^{69}$ Recently, josamycin, a macrolide antibiotic, and fluoroquinolones have been used in other rickettsioses, 3,107 and they could also be effective against $R$. felis.

Although infection with $R$. felis may be self-limiting, disease should be treated due to the possibility of severe illness and complications. ${ }^{62,72,75}$ The prompt and specific laboratory diagnosis of the diseases is very important, not only because it will help the patient's condition, but also in order to avoid using other antibiotics that may lead to selection of resistant bacteria, or other useless therapies like intravenous immunoglobulin in cases where Kawasaki disease has been suspected. ${ }^{81}$

\section{Conclusion}

The present review endorses the importance of $R$. felis as a pathogen to be considered in human cases presenting clinical symptoms that are common to many infectious diseases caused by different rickettsial species and other microorganisms. Human cases of flea-borne spotted fever have been described to date in almost 20 countries around the world. Since the main vector and reservoir, C. felis felis, is a common ectoparasite of dogs and cats globally, infection by $R$. felis is probably more common than reported. Misdiagnosis may be frequent in many cases due to poor awareness and information, as well as minimum or no availability of specific laboratory testing required to implicate $R$. felis directly. Although symptomatic cases are usually mild, there are reports of severe disease where treatment is essential. Considering that $R$. felis infections can be treated in the same manner as other rickettsiae (doxycycline is the drug of choice), timely diagnosis and treatment is important to prevent complications and severe outcomes. Therefore, public health authorities should increase awareness and diagnosis of $R$. felis, especially in developing countries, in order to recognize the presence of this global emerging disease.

\section{Disclosure}

The authors report no conflicts of interest in this work.

\section{References}

1. Raoult D, Roux V. Rickettsioses as paradigms of the new or emerging infectious diseases. Clin Microbiol Rev. 1997;10(4):694-719.

2. Stothard D, Fuerst P. Evolutionary analysis of the spotted fever and thyphus groups of rickettsia using $16 \mathrm{~S}$ rRNA gene sequences. Syst Appl Microbiol. 1995;18(1):52-61.

3. Parola P, Paddock CD, Raoult D. Tick-borne rickettsioses around the world: emerging diseases challenging old concepts. Clin Microbiol Rev. 2005;18(4):719-756.

4. Vitale G, Mansuelo S, Rolain JM, Raoult D. Rickettsia massiliae human isolation. Emerg Infect Dis. 2006;12(1):174-175.

5. Gillespie JJ, Beier MS, Rahman MS, et al. Plasmids and rickettsial evolution: insight from Rickettsia felis. PloS One. 2007;2(3):e266.

6. Weinert LA, Werren JH, Aebi A, Stone GN, Jiggins FM. Evolution and diversity of Rickettsia bacteria. BMC Biology. 2009;7(6):1-15.

7. Fournier PE, Raoult D. Current knowledge on phylogeny and taxonomy of Rickettsia spp. Ann N Y Acad Sci. 2009;1166:1-11.

8. Merhej V, Notredame C, Royer-Carenzi M, Pontarotti P, Raoult D. The rhizome of life: the sympatric Rickettsia felis paradigm demonstrates the random transfer of DNA sequences. Mol Biol Evol. 2011;28(11):3213-3223.

9. Adams JR, Schmidtmann ET, Azad AF. Infection of colonized cat fleas, Ctenocephalides felis (Bouché), with a Rickettsia-like microorganism. Am J Trop Med Hyg. 1990;43(4):400-409.

10. Azad AF, Sacci JBJ, Nelson WM, et al. Genetic characterization and transovarial transmission of a typhus-like rickettsia found in cat fleas. Proc Natl Acad Sci U SA. 1992;89:43-46.

11. Radulovic S, Higgins J, Jaworski D, Dasch G, Azad A. Isolation, cultivation, and partial characterization of the ELB agent associated with cat fleas. Infect Immun. 1995;63(12):4826-4829.

12. Williams SG, Sacci JB, Schriefer ME, et al. Typhus and typhuslike rickettsiae associated with opossums and their fleas in Los Angeles County, California. J Clin Microbiol. 1992;30(7):1758-1762.

13. Higgins J, Radulovic S, Schriefer ME, Azad AF. Rickettsia felis: a new species of pathogenic rickettsia isolated from cat fleas. J Clin Microbiol. 1996;34(3):671-674.

14. Bouyer DH, Stenos J, Crocquet-Valdes P, et al. Rickettsia felis: molecular characterization of a new member of the spotted fever group. Int J Syst Evol Microbiol. 2001;51:339-347.

15. Scola B La, Meconi S, Fenollar F, Rolain JM. Emended description of Rickettsia felis (Bouyer et al, 2001), a temperature-dependent cultured bacterium. Int J Syst Evol Microbiol. 2002;52:2035-2041. 
16. Stevenson HL, Labruna MB, Montenieri JA, et al. Detection of Rickettsia felis in a New World flea species, Anomiopsyllus nudata (Siphonaptera: Ctenophthalmidae). J Med Entomol. 2005;42(2):163-167.

17. Bitam I, Parola P, De La Cruz KD, et al. First molecular detection of Rickettsia felis in fleas from Algeria. Am J Trop Med Hyg. 2006;74(4): 532-535.

18. Venzal JM, Martinez-Perez L, Felix ML, et al. Prevalence of Rickettsia felis in Ctenocephalides felis and Ctenocephalides canis from Uruguay. Ann NYAcad Sci. 2006;1078:305-308.

19. Horta MC, Chiebao DP, de Souza DB, et al. Prevalence of Rickettsia felis in the fleas Ctenocephalides felis felis and Ctenocephalides canis from two Indian villages in Sao Paulo Municipality, Brazil. Ann NY Acad Sci. 2006;1078:361-363.

20. Oliveira K, Oliveira L, Dias C, et al. Molecular identification of Rickettsia felis in ticks and fleas from an endemic area for Brazilian Spotted Fever. Mem Inst Oswaldo Cruz. 2008;103(2):191-194.

21. Eremeeva ME, Warashina W, Sturgeon M, et al. Rickettsia typhi and R. felis in rat fleas (Xenopsylla cheopis), Oahu, Hawaii. Emerg Infect Dis. 2008;14(10):1613-1615.

22. Reif KE, Macaluso KR. Ecology of Rickettsia felis: a review. J Med Entomol. 2009;46(4):723-736.

23. Behar A, McCormick LJ, Perlman SJ. Rickettsia felis infection in a common household insect pest, Liposcelis bostrychophila (Psocoptera: Liposcelidae). Appl Environ Microbiol. 2010;76(7):2280-2285.

24. Nogueras MM, Pons I, Ortuño A, Lario S, Segura F. Rickettsia felis in fleas from Catalonia (Northeast Spain). Vector Borne Zoonotic Dis. 2011;11(5):479-483.

25. Reeves WK, Loftis AD, Sanders F, et al. Borrelia, Coxiella, and Rickettsia in Carios capensis (Acari: Argasidae) from a brown pelican (Pelecanus occidentalis) rookery in South Carolina, USA. Exp Appl Acarol. 2006;39(3-4):321-329.

26. Gilles J, Just FT, Silaghi C, et al. Rickettsia felis in fleas, Germany. Emerg Infect Dis. 2008;14(8):1294-1296.

27. Boudebouch N, Sarih M, Beaucournu J, et al. Bartonella clarridgeiae, B. henselae and Rickettsia felis in fleas from Morocco. Ann Trop Med Parasitol. 2011;105(7):493-498.

28. Loftis AD, Reeves WK, Szumlas DE, et al. Rickettsial agents in Egyptian ticks collected from domestic animals. Exp Appl Acarol. 2006;40:67-81.

29. Rolain JM, Bitam I, Buffet S, et al. Presence or absence of plasmid in Rickettsia felis depending on the source of fleas. Clin Microbiol Infect. 2009;15 Suppl 2:S296-S297.

30. Baldridge GD, Burkhardt NY, Labruna MB, et al. Wide dispersal and possible multiple origins of low-copy-number plasmids in Rickettsia species associated with blood-feeding arthropods. Appl Environ Microbiol. 2010;76(6):1718-1731.

31. Fournier PE, Belghazi L, Robert C, et al. Variations of plasmid content in Rickettsia felis. PloS One. 2008;3(5):1-6.

32. Pérez-Osorio CE, Zavala-Velázquez JE, Arias León JJ, Zavala-Castro JE. Rickettsia felis as emergent global threat for humans. Emerg Infect Dis. 2008;14(7):1019-1023.

33. Znazen A, Raoult D. Flea-borne spotted fever. In: Raoult D, Parola P, editors. Rickettsial Diseases. New York, NY: Informa Heathcare; 2007:87-96.

34. Abdad MY, Stenos J, Graves S. Rickettsia felis, an emerging fleatransmitted human pathogen. Emerg Health Threats J. 2011;4:7168.

35. Parola P. Rickettsia felis: from a rare disease in the USA to a common cause of fever in sub-Saharan Africa. Clin Microbiol Infect. 2011;17: 996-1000.

36. Raoult D, Scola B La, Enea M, et al. A flea-associated Rickettsia pathogenic for humans. Emerg Infect Dis. 2001;7(1):73-81.

37. Márquez FJ, Muniain MA, Pérez JM, Pachón J. Presence of Rickettsia felis in the cat flea from Southwestern Europe. Emerg Infect Dis. 2002;8(1):89-91.

38. Oliveira RP, Galvao MA, Mafra CL, et al. Rickettsia felis in Ctenocephalides spp. fleas, Brazil. Emerg Infect Dis. 2002;8(3): 317-319.
39. Rolain JM, Franc M, Davoust B, Raoult D. Molecular detection of Bartonella quintana, B. koehlerae, B. henselae, B. clarridgeiae, Rickettsia felis, and Wolbachia pipientis in cat fleas, France. Emerg Infect Dis. 2003;9(3):338-342.

40. Parola P, Sanogo OY, Lerdthusnee K, et al. Identification of Rickettsia spp. and Bartonella spp. in from the Thai-Myanmar border. Ann NY Acad Sci. 2003;990:173-181.

41. Kelly PJ, Meads N, Theobald A, Fournier PE, Raoult D. Rickettsia felis, Bartonella henselae, and B. clarridgeiae, New Zealand. Emerg Infect Dis. 2004;10(5):967-968.

42. Henry KM, Jiang J, Rozmajzl PJ, et al. Development of quantitative real-time PCR assays to detect Rickettsia typhi and Rickettsia felis, the causative agents of murine typhus and flea-borne spotted fever. $\mathrm{Mol}$ Cell Probes. 2007;21(1):17-23.

43. Reif KE, Stout RW, Henry GC, Foil LD, Macaluso KR. Prevalence and infection load dynamics of Rickettsia felis in actively feeding cat fleas. PloS One. 2008;3(7):e2805.

44. Pornwiroon W, Pourciau SS, Foil LD, Macaluso KR. Rickettsia felis from cat fleas: isolation and culture in a tick-derived cell line. Appl Environ Microbiol. 2006;72(8):5589-5595.

45. Horta MC, Labruna MB, Durigon EL, Schumaker TTS. Isolation of Rickettsia felis in the mosquito cell line C6/36. Appl Environ Microbiol. 2006;72(2):1705-1707.

46. Hun L, Troyo A, Taylor L, Barbieri AM, Labruna MB. First report of the isolation and molecular characterization of Rickettsia amblyommii and Rickettsia felis in Central America. Vector Borne Zoonotic Dis. 2011;11(10):1395-1397.

47. Wedincamp J, Foil LD. Vertical transmission of Rickettsia felis in the cat flea (Ctenocephalides felis Bouché). J Vector Ecol. 2002;27(1): 96-101.

48. Hirunkanokpun S, Thepparit C, Foil LD, Macaluso KR. Horizontal transmission of Rickettsia felis between cat fleas, Ctenocephalides felis. Mol Ecol. 2011;20(21):4577-4586.

49. Reif KE, Kearney MT, Foil LD, Macaluso KR. Acquisition of Rickettsia felis by cat fleas during feeding. Vector Borne Zoonotic Dis. 2011;11(7):963-968.

50. Macaluso KR, Pornwiroon W, Popov VL, Foil LD. Identification of Rickettsia felis in the salivary glands of cat fleas. Vector Borne Zoonotic Dis. 2008;8(3):391-396.

51. Boostrom A, Beier MS, Macaluso JA, et al. Geographic association of Rickettsia felis-infected opossums with human murine typhus, Texas. Emerg Infect Dis. 2002;8(6):549-554.

52. Richter J, Fournier PE, Petridou J, Häussinger D, Raoult D. Infection acquired in Europe and documented by polymerase chain reaction. Emerg Infect Dis. 2002;8(2):207-208.

53. Case JB, Chomel B, Nicholson W, Foley JE. Serological survey of vector-borne zoonotic pathogens in pet cats and cats from animal shelters and feral colonies. J Feline Med Surg. 2006;8(2):111-117.

54. Oteo JA, Portillo A, Santibañez S, et al. Cluster of cases of human Rickettsia felis infection from Southern Europe (Spain) diagnosed by PCR. J Clin Microbiol. 2006;44(7):2669-2671.

55. Labruna MB, Horta MC, Aguiar DM, et al. Prevalence of Rickettsia infection in dogs from the urban and rural areas of Monte Negro Municipality, Western Amazon, Brazil. Vector Borne Zoonotic Dis. 2007;7(2):249-255

56. Bayliss DB, Morris AK, Horta MC, et al. Prevalence of Rickettsia species antibodies and Rickettsia species DNA in the blood of cats with and without fever. J Feline Med Surg. 2009;11(4):266-270.

57. Nogueras M, Pons I, Ortuño A, Segura F. Seroprevalence of Rickettsia typhi and Rickettsia felis in dogs from north-eastern Spain. Clin Microbiol Infect. 2009; 15 Supp1 2:S237-S238.

58. Lappin MR, Hawley J. Presence of Bartonella species and Rickettsia species DNA in the blood, oral cavity, skin and claw beds of cats in the United States. Vet Dermatol. 2009;20(5-6):509-514.

59. Silva Fortes F, Silveira I, Moraes-Filho J, et al. Seroprevalence of Rickettsia bellii and Rickettsia felis in dogs, São José dos Pinhais, State of Paraná, Brazil. Rev Bras Parasitol Vet. 2010;19(4):222-227. 
60. Horta MC, Scott FB, Correia TR, et al. Rickettsia felis infection in cat fleas Ctenocephalides felis. Braz J Microbiol. 2010;41: 813-818.

61. Horta MC, Sabatini GS, Moraes-Filho J, et al. Experimental infection of the opossum Didelphis aurita by Rickettsia felis, Rickettsia bellii, and Rickettsia parkeri and evaluation of the transmission of the infection to ticks Amblyomma cajennense and Amblyomma dubitatum. Vector Borne Zoonotic Dis. 2010;10(10):959-967.

62. Hii SF, Kopp SR, Abdad MY, et al. Molecular evidence supports the role of dogs as potential reservoirs for Rickettsia felis. Vector Borne Zoonotic Dis. 2011;11(8):1007-1012.

63. Hawley JR, Shaw SE, Lappin MR. Prevalence of Rickettsia felis DNA in the blood of cats and their fleas in the United States. J Feline Med Surg. 2007;9:258-262.

64. Kamrani A, Parreira VR, Greenwood J, Prescott JF. The prevalence of Bartonella, hemoplasma, and Rickettsia felis infections in domestic cats and in cat fleas in Ontario. Can J Vet Res. 2008;72:411-419.

65. Barrs VR, Beatty JA, Wilson BJ, et al. Prevalence of Bartonella species, Rickettsia felis, haemoplasmas and the Ehrlichia group in the blood of cats and fleas in eastern Australia. Aust Vet J. 2010;88(5):160-165.

66. Schriefer ME, Sacci JB, Dumler JS, Bullen MG, Azad AF. Identification of a novel rickettsial infection in a patient diagnosed with murine typhus. J Clin Microbiol. 1994;32(4):949-954.

67. Zavala-Velázquez JE, Ruiz-Sosa JA, Sánchez-Elias RA, Becerra-Carmona G, Walker DH. Rickettsia felis rickettsiosis in Yucatán. Lancet. 2000;356(9235):1079-1080.

68. Zavala-Velazquez J, Laviada-Molina H, Zavala-Castro J, et al. Rickettsia felis, the agent of an emerging infectious disease: report of a new case in Mexico. Arch Med Res. 2006;37(3):419-422.

69. Zavala-Castro J, Zavala-Velazquez J, Walker D, Perez-Osorio J, Peniche-Lara G. Severe human infection with Rickettsia felis associated with hepatitis in Yucatan, Mexico. Int J Med Microbiol. 2009;299:529-533.

70. Renvoise A, Joliot AY, Raoult D. Rickettsia felis infection in man, France. Emerg Infect Dis. 2009;15(7):1126-1127.

71. Pérez-Arellano J, Fenollar F, Angel-Moreno A, et al. Human Rickettsia felis infection, Canary Islands, Spain. Emerg Infect Dis. 2005;11(12):1961-1964.

72. Lindblom A, Severinson K, Nilsson K. Rickettsia felis infection in Sweden: report of two cases with subacute meningitis and review of the literature. Scand J Infect Dis. 2010;42(11-12):906-909.

73. Ben-Zvi I, Meltzer E, Nogueras M, Segura F, Bank I. First detection of human infection with Rickettsia felis in Israel. Am J Med Sci. 2010;340(4):343.

74. Choi YJ, Kim JH, Jang WJ, et al. Spotted fever group and typhus group rickettsioses in humans, South Korea. Emerg Infect Dis. 2005;11(2):237-244.

75. Tsai KH, Lu HY, Tsai JJ, et al. Human case of Rickettsia felis infection, Taiwan. Emerg Infect Dis. 2008;14(12):1970-1972.

76. Parola P, Miller R, McDaniel P, et al. Emerging rickettsioses of the Thai-Myanmar border. Emerg Infect Dis. 2003;9(5):592-595.

77. Phongmany S, Rolain J, Phetsouvanh R, et al. Rickettsial infections and fever, Vientiane, Laos. Emerg Infect Dis. 2006;12(2):256-262.

78. Znazen A, Rolain J, Hammami N, et al. Rickettsia felis infection, Tunisia. Emerg Infect Dis. 2006;12(1):138-140.

79. Kaabia N, Letaief A. Characterization of rickettsial diseases in a hospital-based population in central Tunisia. Ann NY Acad Sci. 2009;1166:167-171.

80. Parker TM, Murray CK, Richards AL, et al. Concurrent infections in acute febrile illness patients in Egypt. Am JTrop Med Hyg. 2007;77(2): 390-392.

81. Williams M, Izzard L, Graves SR, Stenos J, Kelly JJ. First probable Australian cases of human infection with Rickettsia felis (cat-flea typhus). Med J Aust. 2011;194(1):41-43.

82. Socolovschi C, Mediannikov O, Sokhna C, et al. Rickettsia felisassociated uneruptive fever, Senegal. Emerg Infect Dis. 2010;16(7): $1140-1142$.
83. Richards AL, Jiang J, Omulo S, et al. Human infection with Rickettsia felis, Kenya. Emerg Infect Dis. 2010;16(7):1081-1086.

84. Maina A, Knobel D, Jiang J, et al. Rickettsia felis infection on febrile patients, Western Kenya, 2007-2010. Emerg Infect Dis. 2012;18(2):328-331.

85. Lim M, Brady H, Hambling $\mathrm{T}$, et al. Rickettsia felis infections, New Zealand. Emerg Infect Dis. 2012;18(1):167-169.

86. Galvão MAM, Mafra C, Chamone CB, et al. Clinical and laboratorial evidence of Rickettsia felis infections in Latin America. Rev Soc Bras Med Trop. 2004;37(3):238-240.

87. Scola B La, Raoult D. Laboratory diagnosis of rickettsioses: current approaches to diagnosis of old and new rickettsial diseases. J Clin Microbiol. 1997;35(11):2715-2727.

88. Fenollar F, Fournier PE, Raoult D. Flea-borne spotted fever. In: Raoult D, Parola P, editors. Rickettsial Diseases. New York: Informa Heathcare; 2007:315-330.

89. Philip RN, Casper EA, Ormsbee RA, Peacock MG, Burgdorfer W. Microimmunofluorescence test for the serological study of Rocky Mountain spotted fever and typhus. J Clin Microbiol. 1976;3(1):51-61.

90. Newhouse VF, Shepard CC, Redus MD, Tzianabos T, McDade JE. A comparison of the complement fixation, indirect fluorescent antibody, and microagglutination tests for the serological diagnosis of rickettsial diseases. Am J Trop Med Hyg. 1979;28(2):387-395.

91. Anacker RL, Mann RE, Gonzales C. Reactivity of monoclonal antibodies to Rickettsia rickettsii with spotted fever and typhus group rickettsiae. J Clin Microbiol. 1987;25(1):167-171.

92. Ormsbee R, Peacock M, Philip R, et al. Antigenic relationships between the typhus and spotted fever groups of rickettsiae. Am J Epidemiol. 1978;108(1):53-59.

93. Bernabeu-Wittel M, del Toro MD, Nogueras MM, et al. Seroepidemiological study of Rickettsia felis, Rickettsia typhi, and Rickettsia conorii infection among the population of southern Spain. Eur J Clin Microbiol Infect Dis. 2006;25(6):375-381.

94. Parola P, Raoult D. Ticks and tickborne bacterial diseases in humans: an emerging infectious threat. Clin Infect Dis. 2001;32(6): 897-928.

95. Jensenius M, Fournier PE, Vene S, et al. Comparison of immunofluorescence, Western blotting, and cross-adsorption assays for diagnosis of African tick bite fever. Clin Diagn Lab Immunol. 2004;11(4):786-788.

96. Nogueras MM, Cardeñosa N, Sanfeliu I, et al. Serological evidence of infection with Rickettsia typhi and Rickettsia felis among the human population of Catalonia, in the Northeast of Spain. Am J Trop Med Hyg. 2006;74(1):123-126.

97. Blair PJ, Jiang J, Schoeler GB, et al. Characterization of spotted fever group rickettsiae in flea and tick specimens from Northern Peru. JClin Microbiol. 2004;42(11):4961-4967.

98. Sakamoto JM, Azad AF. Propagation of arthropod-borne Rickettsia spp. in two mosquito cell lines. Appl Environ Microbiol. 2007;73(20):6637-6643.

99. Sunyakumthorn P, Bourchookarn A, Pornwiroon W, et al. Characterization and growth of polymorphic Rickettsia felis in a tick cell line. Appl Environ Microbiol. 2008;74(10):3151-3158.

100. Thepparit C, Sunyakumthorn P, Guillotte ML, et al. Isolation of a rickettsial pathogen from a non-hematophagous arthropod. PLoS One. 2011;6(1):1-11.

101. Saisongkorh W, El Karkouri K, Patrice JY, et al. Tryptose phosphate broth improves Rickettsia felis replication in mammalian cells. FEMS Immunol Med Microbiol. 2012;64(1):111-114.

102. Parker R, Pickens E, Lackman D, Bell E, Thraikill F. Isolation and characterization of Rocky Mountain spotted fever rickettsiae from the rabbit tick Haemaphysalis leporis-palustris Packard. Public Health Rep. 1951;66(15):455-463.

103. Fuentes L, Calderon A, Hun L. Isolation and identification of Rickettsia rickettsii from the rabbit tick (Haemaphysalis leporispalustris) in the Atlantic zone of Costa Rica. Am J Trop Med Hyg. 1985;34(3): 564-567. 
104. Holman RC, Paddock CD, Curns AT, et al. Analysis of risk factors for fatal Rocky Mountain spotted fever: evidence for superiority of tetracyclines for therapy. Infect Dis. 2001;184:1437-1444.

105. Purvis JJ, Edwards MS. Doxycycline use for rickettsial disease in pediatric patients. Pediatr Infec Dis J. 2000;19(9):871-874.
106. Masters EJ, Olson GS, Scott JW, Paddock CD. Rocky Mountain spotted fever: a clinician's dilemma. Arch Intern Med. 2003;16: 3769-3774.

107. Segura F, Antón E. Clarithromycin for the treatment of Mediterranean spotted fever. Clin Infect Dis. 2002;15;34(4):560.

\section{Publish your work in this journal}

Research and Reports in Tropical Medicine is an international, peerreviewed, open access journal publishing original research, case reports, editorials, reviews and commentaries on all areas of tropical medicine, including: Diseases and medicine in tropical regions; Entomology; Epidemiology; Health economics issues; Infectious disease; Laboratory science and new technology in tropical medicine; Parasitology; Public health medicine/health care policy in tropical regions; and Microbiology. The manuscript management system is completely online and includes a very quick and fair peer-review system. Visit http://www.dovepress. com/testimonials.php to read real quotes from published authors.

Submit your manuscript here: http://www.dovepress.com/research-and-reports-in-tropical-medicine-journal 